\title{
ROOT GRAFTING IN TREES ${ }^{1}$
}

\author{
Carl D. La Rue \\ (Received for publication February I0, I933)
}

Rigg and Harrar (193I) in a study of root systems growing in sphagnum report that "excessive root fusion often occurs in sphagnum peat." They attribute the fusion to the swaying of the trees, which wears away the bark on the roots so that the meristematic areas of different roots are brought into contact. They state also that fusions of the stems of Alnus oregana which have been rubbed together by swaying in the wind are common in the Seattle region.

Small (1932) has described natural grafts in stems of four species of trees. $\mathrm{He}$ believes that rubbing together of the stems, or branches, is the cause of the fusions.

Millner (1932) has studied stem grafting in Hedera helix and has shown that attrition of the bark by rubbing of stems, or by other means, is unnecessary in the process.

Examples of stem grafting in forest trees are known to most botanists and are generally thought to be due to wearing away of the bark at the points of contact by the waving of the branches in the wind. However, the writer has seen grafts in tree stems which could not be explained in this way, and in tropical countries he has observed, in various species of strangling figs, thousands of grafts where the bark had not been disturbed in any way by external means. The strangling figs represent the most remarkable series of natural grafts to be seen anywhere, and it appears that the lightest contact between two branches or two roots is sufficient to cause their union. From these observations the author has been led to question whether any removal of bark by friction is needed to bring about grafting in tree roots.

Comparatively little is known about the root systems of our forest trees, and it is a matter of regret that earlier botanists did not undertake a study of tree roots at a time when great areas in the United States were being denuded of their forests. So little land is being cleared at the present time that one seldom has an opportunity to observe many root systems of any one species. The cost of grubbing out mature trees for the purpose of making studies on their roots is, of course, prohibitive.

Occasionally, opportunities to make root studies on one or two species are offered by circumstances, and it is to be hoped that botanists will take advantage of them before they become even fewer. The present paper represents the utilization of such opportunities.

1 Papers from the Department of Botany, University of Michigan, No. 405. 


\section{SPECIES IN WHICH ROOT GRAFTS ARE COMMON}

Pimus strobus. In these days few of us ever see the root system of a mature white pine exposed, but in the preceding generation vast numbers of stumps of this species were grubbed out, as the areas left by the lumberman were turned into fields. The greater number of the stumps were burned as they were removed, but in certain sections of the state of Michigan and elsewhere great numbers of them were drawn into lines along the boundaries of fields to serve as fences. Here they have remained, undergoing a very gradual decay.

In the neighborhood of Alma, Michigan, there are still hundreds of miles of these fences of white-pine stumps. They are still sound enough to burn well, and many of them are being cut up as a cheap source of fuel.

In this region the writer drove along roads bordered by stump fences for at least ten miles, and according to a conservative estimate he must have seen 3000 stumps in sufficient detail to recognize root grafts on all of them. Not a single stump was seen which did not show some grafts among its roots.

Most of the small roots were cut away when the fences were made, and the remainder have decayed so that only the larger roots are left to show what the original conditions may have been. But as the stumps now appear, the roots are grafted wherever they come into contact with one another. Originally the number of grafts must have been much greater than one can now find, because many of the small roots still present show unions and the roots which have been lost must have borne a great many more.

Even as they now lie, the stumps frequently are partially buried in the soil and débris, so that numerous grafts are hidden, and there are complexes of roots which conceal many others. Table I presents the data secured from actual counts on 50 stumps, and figure I shows the actual appearance of a typical example. In almost every case there were undoubtedly other junctions which were partially or completely concealed.

TABLE I. Root grafts on stumps of Pinus strobus and Thuja occidentalis

\begin{tabular}{ccc}
$\begin{array}{c}\text { Numbers of } \\
\text { root grafts }\end{array}$ & $\begin{array}{c}\text { Stumps of } \\
\text { Pinus strobus }\end{array}$ & $\begin{array}{c}\text { Stumps of } \\
\text { Thuja occidentalis }\end{array}$ \\
\hline I-10 & & 22 \\
I I-20 & 4 & $3 \mathrm{I}$ \\
$2 \mathrm{I}-30$ & $\mathrm{II}$ & $\mathrm{I} 9$ \\
$3 \mathrm{I}-40$ & $\mathrm{I} 2$ & 9 \\
$4 \mathrm{I}-50$ & 8 & 4 \\
$5 \mathrm{I}-60$ & 5 & 7 \\
$6 \mathrm{I}-70$ & 3 & 3 \\
$7 \mathrm{I}-80$ & $\mathrm{I}$ & 5 \\
$8 \mathrm{I}-90$ & 3 & - \\
$9 \mathrm{I}-\mathrm{I} 00$ & $\mathrm{I}$ & - \\
IOI-II0 & 2 & $\mathrm{I}$ \\
I I I-120 & 50 & IOI \\
Totals & & \\
\hline
\end{tabular}


In only one instance were the roots of two stumps found grafted together. Here a small stump was united to a large one by unions of several large roots, so that the two could have been separated only with difficulty (fig. I). Such unions of separate root systems could not have been very numerous because the large trees did not form a very close stand, but several men who have
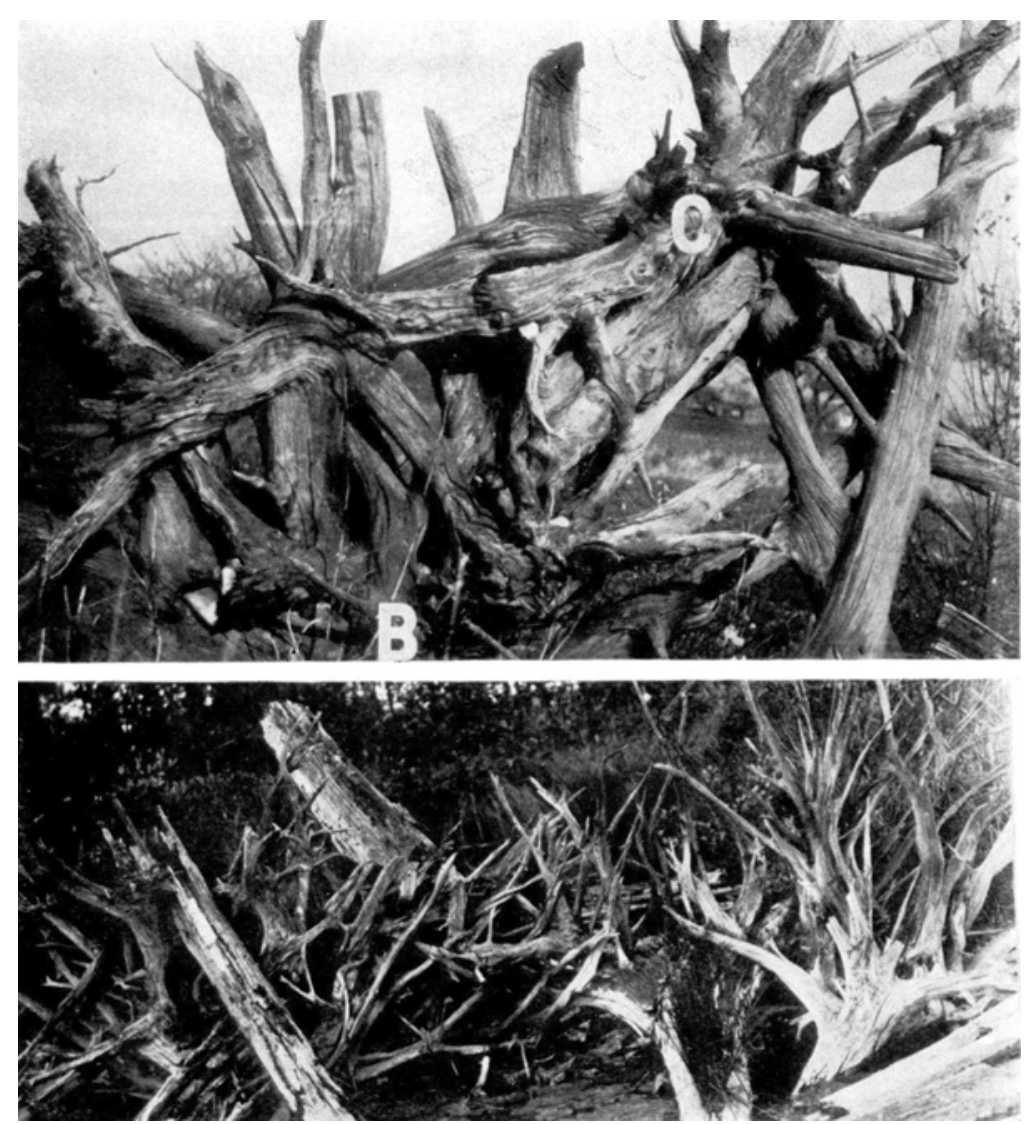

Fig. I (above). Root grafts in Pinus strobus. Two separate trees, whose roots are fused together, are represented. The base of a large tree is shown at $B$; that of a smaller one at $C$.

Fig. 2 (below). Grafts on the roots of Thuja occidentalis. This plexus involves the roots of several trees.

built sttimp fences in the past have assured the writer that stumps were often so firmly united that they had to be pulled at the same time and chopped apart before they could be placed in the fence rows.

Although definite counts were not made to settle the question, it appeared that the root unions were more numerous on stumps which had grown on 
low land. The roots were smaller in the lower lands, and it may well be that they were confined to the upper layers of the soil by the high-water table. The greater competition of the roots in the upper soil would be expected to give rise to more root contacts and more grafts. Stumps of trees grown on sandy upland soil and on clay hills showed larger roots, but there was no lack of grafts on any of these.

Thuja occidentalis. Along a small stream, known locally as Nigger Creek, which flows into Mullet Lake near Topinabee, Michigan, the writer found a number of unprotected trees of Thuja occidentalis. Apparently the meandering stream has cut away the soil from these trees so that they have toppled over with their roots exposed. These trees are rather small, ranging from 10 to $100 \mathrm{~cm}$. in diameter, and nearly all the roots are small. The roots were confined to a layer scarcely more than $3^{\circ} \mathrm{cm}$. thick, and competition be tween them was obviously severe.

The soil here is a black muck, easily penetrated by the roots, but sufficiently firm to give good support to the trees. All but the smallest roots are still intact on most of the trees, so that one can see that they were exceedingly numerous and that contacts between them were very common. Wherever they came into close contact they have grown together. Table I shows the numbers of grafts counted on ror of these trees, and figure 2 gives an idea of their appearance. It is certain that only a small part of the grafts was visible, for compact masses of small roots were often encountered in which great numbers of unions were concealed.

Grafts between roots of different trees were very common, since the trees had grown in a close stand. Of the trees listed in table r, 64 showed unions with at least one other tree. In one place I I stumps were completely knitted togetherr; so that it was often impossible to tell to what tree a root emerging from the plexus originally belonged.

Ulmus americana. Only a small number of trees of this species has been available for study. None of these has been without grafts, and most of them have shown numerous unions regardless of the type of soil in which they grew.

Tilia anericana. Observations on limited numbers of trees of this species reveal root unions in abundance. In one tree that had grown in low ground the roots were spread in a thin flat plate not over ro $\mathrm{cm}$. thick. The tree had been blown over so that this thin root mass was fully exposed. The roots were seen to be united almost into a solid mass by myriad grafts. It seems that this species is one in which root fusions occur very readily-more readily than in most others.

Betula lutea. Grafts are very numerous on roots of yellow birch trees. The trees examined were growing on a black soil in a rather wet location. and accordingly the roots were spread out in a thin layer near the surface, where they crossed one another repeatedly and fused at nearly every crossing.

Acer saccharinum. Under conditions identical with those described for Betula lutea, trees of Acer saccharinum produce great numbers of root grafts. 
SPECIES WHICH DO NOT FORM ROOT GRAFTS READILY

Larix laricina. A few larch trees were seen which had been uprooted so that all but the outer ends of the roots could be seen. It was obvious that if any root grafts were formed they were very few. Without a complete dissection of the root systems it was impossible to be certain that no grafts were present, but none could be found on the smaller roots. Many roots were found which lay in grooves in others, but in none of these was there any fusion whatsoever. This behavior contrasted strikingly with that of the roots of all the species described earlier in this paper.

The tamarack trees had grown in the lowest and least solid ground of any observed in this study, so that they should have had greater opportunity to sway and wear away the bark between the roots than any of the others.

Populus tremuloides. The roots of this species appear to fall into the same class as those of the tamarack. No root grafts could be made out with certainty. None were found between any of the roots which could be flexed, for several apparent fusions proved not to be what they seemed. The roots could always be pulled apart, showing that they had grown around one another, but had not fused at all. It is possible that in some of the large roots which are forced together by continued growth actual fusions may occur, but none has been seen.

Fraxinus nigra. Root fusions do not appear to take place between roots of the black ash, but too few trees have been examined to determine the facts for this species.

Prumus serotina. The exposed roots of a few trees have been seen, and on these no grafts have been found. One tree was found in a wet habitat, and in this the root crown was set up about $20 \mathrm{~cm}$. above the soil, with small roots extending down into the earth. This was a small tree and could be swayed back and forth with the hands, so that the roots were flexed and rubbed against one another. It appeared that the winds had swayed this tree, for some of the roots showed abraded and worn surfaces where they came into contact, but the cambium had not been exposed sufficiently to induce any fusions.

\section{GRAFTS BETWEEN DIFFERENT SPECIES}

Roots of Betula lutea were found which were firmly united to roots of Ulmus americana. There could be no question that a strong union was formed, for the roots could not be pulled apart. The exact nature of the fusion remains to be determined.

Some roots of Betula lutea appeared to be grafted with those of Acer saccharinum, but since the roots were large, they could not be bent so as to determine whether the roots were merely grown around each other or really fused. 


\section{DISCUSSION}

Millner (1932) has shown that stems of Hedera helix grow together without the exposure of the cambium by any external means. Small (I932) mentions the rubbing of branches as a possible factor in stem and branch grafts in four species, but shows a picture of a head-on graft between branches of Taxodium ascendans in which abrasion must have played a minor rôle.

Rigg and Harrar (193I) believe that root fusions in Pinus monticola growing in sphagnum are due to attrition of the bark as the roots are flexed when the trees are blown back and forth by the wind. Root grafting in Pinu; strobus cannot be caused by wind action because large trees growing in stiff clay could not conceivably have been swayed enough to wear away the bark on the roots before the fusions took place. It is hardly more likely that the vast number of root unions in Thuja americana could have a connection with wind action than that those of Pinus strobus could.

Tamaracks growing in peaty soil where wind sway might be possible do not bear root grafts, and the one tree of cherry which showed some abrasion of bark, apparently due to wind action, produced no root fusions.

The soil plays a part in the grafting of roots in Pinus strobus, Thuja occidentalis, Ulmus americana, Betula lutea, Tilia americana, and Acer saccharinum, by serving as a support that prevents growth in diameter from pushing apart the roots which have come into contact with each other. On the contrary, it tends to keep the roots pressed firmly together so that the reactions which result in fusions may be induced. The nature of the root systems of a given species may be such as to give rise to a great or to a small number of root contacts. The nature of the cambium probably determines whether or not root grafts take place readily between roots held together by the combined action of centrifugal growth and the soil.

\section{SUMMARY}

I. Root grafts are common in Pinus strobus, Thuja occidentalis, Ulmus americana, Betula lutea, Tilia americana, and Acer saccharimum.

2. The roots of Larix laricina, Fraxinus nigra, and Prunus serotina seem not to fuse together readily.

3. Removal by friction of the bark at the point of contact between two roots is not necessary to produce root grafts in the species discussed in this paper.

University of Michigan, Ann Arbor, Michigan

\section{LITERATURE CITED}

Millner, M. Ethelwyn. 1932. Natural grafting in Hedera heli.r. New Phytol. 31: I-25.

RigG, G. B., and E. S. Harrar. I93I. The root systems of trees growing in sphagnum. Amer. Jour. Bot. 18: 391-397.

Small, J. K. 1932. Natural grafts. Jour. New York Bot. Gard. 33: 213-219. 